\title{
PELAKSANAAN PEMBELAJARAN CBSA DALAM USAHA MENINGKATKAN HASIL BELAJAR BIDANG STUDI PENDIDIKAN KEWARGANEGARAAN DI SEKOLAH MENENGAH PERTAMA (SMP) BHINA KARYA RONGKOP KABUPATEN GUNUNGKIDUL TAHUN 2014
}

\author{
Oleh: \\ Eka Supriyanta \\ Universitas Cokroaminoto Yogyakarta
}

\begin{abstract}
Abstrak
Tujuan dan penelitian ini adalah untuk mengetahui sejauh mana peran CBSA dalam peningkatan hasil belajar bidang studi Pendidikan Kewarganegaraan di Sekolah Menengah Pertama (SMP) Bhina Karya Rongkop Kabupaten Gunungkidul.

Metode dalam penelitian dengan metode observasi, populasi dalam penelitian ini semua siswa dan guru bidang studi Pkn Sekolah Menengah Pertama (SMP) Bhina Karya Rongkop Kabupaten Gunungkidul. Dalam penelitian ini subjek penelitian yang diambil adalah kelas VII sebanyak 25 siswa. Peneliti menggunakan analisa kuantitatif untuk mengetahui sejauhmana peran CBSA dapat meningkatkan hasil belajar bidang studi Pendidikan Kewarganegaraan di Sekolah Menengah Pertama (SMP) Bhina Karya Rongkop Kabupaten Gunungkidul.

Hasil penelitian metode CBSA dapat meningkatkan hasil belajar bidang studi Pendidikan Kewarganegaraan di Sekolah Menengah Pertama (SMP) Bhina Karya Rongkop Kabupaten Gunungkidul. Hal ini dapat dilihat dari nilai rata-rata bidang Studi Pendidikan Kewarganegaraan sebagian besar mendapat nilai di atas (7) tujuh. Dari skor rata-rata evaluasi meskipun begitu dalam pelaksanaan CBSA masih terdapat hambatan, dari pihak guru antara lain kurang memperkaya diri dengan pengetahuan (kognitif), dari siswa kesadaran belajarnya masih kurang dan dari pihak orang tua kurang adanya komunikasi dengan guru terhadap pembinaan anak.
\end{abstract}

Kata kunci: Pembelajaran, CBSA, Pendidikan Kewarganegaraan, hasil belajar.

\section{A. Pendahuluan}

Dalam kurun waktu terakhir ini tantangan pendidikan semakin nyata bersamaan dengan tumbuh dan berkembangnya masyarakat sebagai akibat diri kemajuan ilmu pengetahuan dan teknologi. Sedangkan dalam lembaga pendidikan sendiri masih mencari bentuk yang sesuai dengan tuntutan masyarakat. Masalah yang dihadapi lembaga pendidikan dewasa ini adalah berkenaan dengan berkurangnya kemampuan siswa dalam mengembangkan konsep-konsep ilmu yang diterimanya, baik berupa pengetahuan, keterampilan maupun sikap dalam bentuk dan 
situasi yang lain. Siswa meskipun mendapat nilai yang tinggi dalam sejumlah mata pelajaran namun apabila mereka dihadapkan pada kenyataan-kenyataan yang lain nampak mereka kurang mampu menerapkan perolehannya.

Langkah sistematis dalam proses pembelajaran merupakan bagian penting dari strategi pembelajaran yakni usaha guru dalam mengatur dan menggunakan komponen-komponen pembelajaran agar mempengaruhi siswa dalam mencapai tujuan yang telah ditentukan.

Mengingat posisi dan peranan guru yang berhadapan langsung dengan siswa melalui proses pembelajaran di sekolah, maka upaya meningkatkan kualitas proses dan hasil pembelajaran sebagian besar menjadi tugas dan tanggung jawab guru. Untuk itu dalam kurikulum dikembangkan strategi mengajar yang menekankan pada keaktifan siswa dalam belajar, yang dikenal dengan pendekatan cara belajar siswa aktif. Tetapi sebagaimana layaknya suatu kegiatan pendidikan dan pembelajaran akan berhasil apabila didukung oleh beberapa faktor penentu, yaitu:

1. Tujuan pengajaran

2. Materi/bahan pelajaran yang akan dibahas

3. Guru sebagai pengajar/penyaji bahan pelajaran

4. Murid sebagai pelajar yang akan mengambil/menerima bahan pelajaran untuk diolah/dimiliki.

5. Metode/prosedur penyampaian bahan pelajaran

6. Alat pengajaran yaitu alat bantu untuk memudahkan pembahasan. (JJ. Hasibuan, 1984:6)

Menurut pendapat lain Sutari Imam Barnadib dikatakan bahwa faktor-faktor pendidikan meliputi:

1. Faktor tujuan

2. Faktor pendidik.

3. Faktor anak didik.

4. Faktor alat.

5. Faktor alam sekitar/millieu. (1987: 35)

Kondisi dan eksistensi faktor-faktor tersebutlah yang sangat mempengaruhi keberhasilan suatu proses pendidikan dan pembelajaran dimana dari masing-masing komponen tersebut harus saling menunjang dan mengisi. Pendidikan Kewarganegaraan di Sekolah Menengah Pertama 
adalah merupakan bagian yang integral dari program pembelajaran serta usaha sadar untuk menyiapkan peserta didik menjadi warga negara yang bertanggung jawab. Dalam kurikulum Departemen Pendidikan Nasional tahun 2006 Pendidikan Kewarganegaraan adalah merupakan mata pelajaran yang memfokuskan pada pembentukan warga negara yang memahami dan mampu melaksanakan hak-hak dan kewajibannya untuk menjadi warga negara Indonesia yang cerdas, terampil, dan berkarakter yang diamanatkan oleh Pancasila dan UUD 1945 (2006: 232). Jadi tujuan pembelajaran PKn adalah menciptakan warga negara yang cerdas, terampil dan berkarakter.

Dalam melakukan kegiatan pembelajaran yang dicapai melalui proses yang bersifat aktif siswa menggunakan seluruh kemampuan dasar yang dimilikinya sebagai dasar melakukan berbagai kegiatan agar memperoleh hasil yang baik. Sebetulnya CBSA dalam istilah lain dapat disebut Student Active Learning (SAL) bukan merupakan, barang baru dalam dunia pendidikan setidak-tidaknya sebagai suatu konsep meskipun sepenuhnya dapat terwujud dalam pelaksanaan kegiatan belajar mengajar. Menurut Dr. Nana Sudjana bahwa CBSA adalah suatu proses kegiatan belajar mengajar yang subyek didiknya terlibat secara intelektual dan emosional sehingga is betul-betul berperan dan berpartisipasi aktif dalam melakukan kegiatan belajar. (1989: 20). Sedangkan menurut Cece Wijaya dkk. dalam bukunya yang berjudul : "Upaya pembaharuan dalam Pendidikan dan Pengajaran", CBSA dapat diartikan sebagai suatu sistem belajar mengajar yang menekankan keaktifan siswa secara fisik, mental, intelektual dan emosional guna memperoleh hasil belajar yang berupa perpaduan antara matra (domein) kognitif, afektif dan psikomotorik. (1992: 10).

Dari definisi di atas menunjukkan bahwa CBSA menempatkan siswa sebagai inti dalam pembelajaran. Siswa bukan hanya dipandang sebagai obyek pendidikan tetapi sekaligus yang mempunyai potensi dan kemampuan berpikir. Di dalam CBSA tidak bermaksud melupakan peranan guru di dalam menciptakan lingkungan. Guru di dalam menyampaikan bahan pelajaran diharapkan tidak terpaku kepada salah satu metode mengajar saja, tetapi guru harus menggunakan metode yang bervariasi terutama untuk mengaktifkan siswa dalam belajar sehingga suasana proses belajar mengajar akan nampak lebih hidup dan menyenangkan.

Untuk melaksanakan metode mengajar yang mengacu kepada siswa aktif harus tersedia sarana belajar yang memadai seperti buku paket, alat peraga, kelengkapan laboratorium dan sebagainya, 
karena proses belajar mengajar yang berkadar CBSA tinggi maka tidak mungkin akan berjalan dengan baik tanpa didukung oleh sarana belajar yang memadai. Untuk melihat terwujudnya CBSA dalam proses belajar mengajar terdapat beberapa indikator CBSA. Melalui Indikator CBSA dapat dilihat tingkah laku mana yang muncul dalam proses belajar mengajar berdasarkan apa yang dirancang oleh guru. Indikator tersebut dilihat dari lima segi yakni:

a. Dari sudut siswa dapat dilihat dari

1) Keinginan, keberanian menampilkan minat, kebutuhan dan permasalahannya.

2) Keinginan dan keberanian serta kesempatan untuk berpartisipasi dalam kegiatan, persiapan, proses dan kelanjutan belajar.

3) Penampilan berbagai usaha atau kekreatifan belajar dalam menjalani dan menyelesaikan kegiatan belajar mengajar sampai mencapai keberhasilannya.

4) Kebebasan atau keluasan melakukan hal tersebut di atas tanpa tekanan guru atau pihak lainnya (kemandirian belajar).

b. Dilihat dari sudut guru, tampak

1) Adanya usaha mendorong, membina, gairah belajar dan berpartisipasi siswa secara aktif.

2) Bahwa peranan guru tidak mendominasi kegiatan proses belajar siswa.

3) Bahwa guru memberi kesempatan kepada siswa untuk belajar menurut cara dan keadaan masing-masing

4) Bahwa guru menggunakan berbagai jenis metode mengajar serta pendekatan multimedia.

c. Dilihat dari segi program, hendaknya:

1) Tujuan instruksional serta konsep maupun isi pelajaran Itu sesuai kebutuhan, minat serta kemampuan subyek didik.

2) Program cukup jelas dapat dimengerti siswa dan menantang siswa untuk melakukan kegiatan belajar.

3) Bahan pelajaran mengandung fakta atau informasi konsep, prinsip dan keterampilan.

d. Dilihat dari situasi belajar, tampak adanya

1) Iklim hubungan intim dan erat antara guru dengan siswa, siswa dengan siswa guru dengan guru serta dengan unsur pimpinan sekolah

2) Gairah serta kegembiraan belajar siswa sehingga siswa memiliki motivasi yang kuat serta keleluasaan mengembangkan cara belajar masing-masing. 
e. Dilihat dari sarana belajar, tampak adanya:

1) Sumber-sumber belajar bagi siswa

2) Fleksibilitas waktu untuk melakukan kegiatan belajar.

3) Dukungan dari berbagai jenis media pengajaran.

4) Kegiatan belajar siswa yang tidak terbatas di dalam kelas, tetapi juga di luar

Dengan adanya tanda-tanda di atas, akan lebih mudah bagi guru dalam merencanakan dan melaksanakan pengajaran. Setidak-tidaknya memberikan rambu-rambu bagi guru dalam melaksanakan CBSA. Cara belajar siswa aktif perlu dikembangkan, karena cara belajar siswa aktif secara faktual dapat meningkat kadar keaktifan siswa.

Berdasarkan hal di atas, maka guru yang menggunakan berbagai macam metode dalam pembelajaran, sarana belajar yang memadai diharapkan anak didik dapat belajar secara efektif dan efisien dan sesuai tujuan yang diharapkan.

Untuk menentukan/memilih metode yang tepat dalam Pendidikan Kewarganegaraan dengan pelaksanaan CBSA.

a. Tujuan yang berbagai-bagai jenis dan fungsinya

b. Anak didik yang berbagai-bagai tingkat kematangannya

c. Situasi yang berbagai-bagai keadaannya

d. Fasilitas yang berbagai-bagai kualitas dan kuantitasnya

Penelitian ini bertujuan untuk mengetahui bagaimanakah pelaksanaan CBSA dalam pembelajaran Pkn di Sekolah Menengah Pertama (SMP) Bhina Karya Rongkop Kabupaten Gunungkidul dan mengetahui apakah pelaksanaan CBSA dapat meningkatkan hasil belajar PKn pada semester I di Sekolah Menengah Pertama (SMP) Bhina Karya Rongkop Kabupaten Gunungkidul. Penelitian ini dapat bermanfaat bagi perkembangan ilmu pengetahuan dan implementasi pelaksanaan CBSA dalam pembelajaran PKn dan dapat digunakan sebagai bahan acuan selanjutnya. Selain itu, hasil penelitian ini dapat menjadi bahan masukan di sekolah yang bersangkutan dan sumbangan pemikiran untuk pengembangan pendidikan pada umumnya dalam bidang studi PKn khususnya. 


\section{B. Metode Penelitian}

Penelitian ini berlangsung dari tanggal 5 Nopember sampai dengan tanggal 6 Desember 2014. Adapun tempat yang diteliti dalam hal ini adalah Sekolah Menengah Pertama (SMP) Bhina Karya Rongkop Kabupaten Gunungkidul. Variabel dalam penelitian ini adalah pelaksanaan Pembelajaran CBSA dalam usaha meningkatkan hasil belajar bidang studi PKn. Subjek penelitiannya adalah guru 1 orang, siswa 20 orang dan Kepala sekolah. Tujuannya bahwa subjek tidak hanya siswa dan guru tetapi Kepala sekolah dijadikan sumber data agar penelitian ini lebih valid.

Teknik pengumpulan data dalam penelitian ini adalah observasi, wawancara, dan dokumentasi. Peneliti mengadakan pengamatan langsung di lapangan terhadap gejala-gejala yang diselidiki. Dalam metode observasi mencatat dan mengamati secara sistematis terhadap fenomina-fenomina yang terdapat ditempat penelitian yaitu di SMP Bhinakarya Rongkop. Dalam penelitian ini adalah dengan wawancara dan tanya jawab secara mendalam guna memperoleh informasi yang dilakukan terhadap orang-orang atau subjek penelitian. Dokumentasi digunakan untuk menunjang hasil penelitian. Dokumen yang dimaksud adalah barang-barang yang tertulis, dalam penelitian ini dokumen yang diperlukan adalah data-data yang relevan dengan tujuan peneliti. Data tersebut adalah nilai atau prestasi belajar siswa Sekolah Menengah Pertama (SMP) Bhina Karya Rongkop Kabupaten Gunungkidul.

Dengan melalui analisis data ini dikumpulkan kemudian diolah menjadi data yang matang. Data penelitian ini adalah deskriptif kualitatif yaitu data-data yang telah diperoleh kemudian digambarkan melalui kata-kata atau kalimat. Langkah-langkah dalam menganalisis data adalah sebagai berikut:

1. Reduksi data

Dalam tahap ini yaitu proses pemilahan pada penyederhanaan data-data yang diperoleh di lapangan diringkas dan diberi tanda.

2. Display data

Setelah data direduksi untuk langkah selanjutnya adalah penyajian data. Dalam penelitian ini disajikan dalam bentuk uraian singkat, bagian, hubungan antar kategori.

3. Mengambil kesimpulan/verifikasi data 
Data yang sudah diperoleh kemudian diambil kesimpulannya sedangkan verifikasi adalah cara mempelajari data-data yang ada. Agar data penelitian valid maka juga ditanyakan pada pihak lain yaitu kepala sekolah. Triangulasi yaitu membandingkan data yang diperoleh dari hasil observasi wawancara dan dokumentasi untuk mengetahui hasil kebenarannya data tersebut dilakukan croscek.

\section{Hasil Penelitian dan Pembahasan}

Dari data-data yang terkumpul, di antaranya data guru kelas, jumlah murid, nilai rata-rata bidang studi PKn semester I tahun pelajaran 2014/2015 serta data tentang skor jawaban guru dan skor jawaban siswa kelas VII - IX. Dari data-data tersebut di atas dipandang yang perlu dianalisis yaitu:

1. Data tentang nilai rata-rata bidang studi PKn Semester I Tahun Pelajaran 2014/2015. Data ini dimaksudkan untuk mencari apakah dari nilai rata-rata tersebut dapat diketahui bahwa pelaksanaan CBSA dapat meningkatkan prestasi belajar siswa. Hal ini dilihat dari hasil belajar sebelum menggunakan metode CBSA dan setelah menggunakan metode CBSA. Nilai evaluasi belajar PKn sebelum menggunakan metode CBSA nilai rat-rata adalah 7,2 dan setelah menggunakan metode CBSA nilai rata-rata menjadi 7,85.

2. Data skor jawaban guru

Data ini dimaksudkan untuk mengetahui seberapa jauh perilaku guru terhadap keberhasilan pelaksanaan program CBSA dapat memberikan tingkatan skor yaitu: rendah, sedang dan tinggi. Menurut data yang kami ambil menunjukkan semua guru kelas VII termasuk tinggi dalam usahanya meningkatkan prestasi nilai belajar siswa melalui program CBSA (Cara Belajar Siswa Aktif)

3. Skor Jawaban murid

Data ini mempunyai maksud untuk mengetahui apakah perilaku siswa mendukung terhadap program CBSA dalam rangka meningkatkan prestasi hasil belajar.

Dari data di atas mempunyai tingkatan skor yaitu : 1 - 9,9 = rendah, $10-18,9=$ sedang dan skor $19-30=$ tinggi.

Dari kenyataan data, menunjukkan sebagian besar siswa termasuk bertingkat tinggi di dalam menanggapi pelaksanaan program CBSA. Dari semua analisa data tersebut di atas penulis dapat 
memberikan prosentase dan semua jawaban guru dan siswa begitu juga dapat diketahui tingkat kevariasian dari jawaban mereka (guru dan siswa) menurut indikator CBSA, antara lain sebagai berikut:

\begin{tabular}{|l|l|l|}
\hline Nomor & Perilaku-perilaku & Persentase \\
\hline 1 & 1 & $90 \%$ \\
2 & 2 & $80 \%$ \\
3 & 3 & $90 \%$ \\
4 & 4 & $80 \%$ \\
\hline
\end{tabular}

Keterangan:

Perilaku 1: Adanya usaha mendorong, membina gairah belajar dan prestasi siswa secara aktif.

Perilaku 2: Bahwa peranan guru tidak mendominasi kegiatan proses pembelajaran siswa

Perilaku 3: Bahwa guru memberi kesempatan kepada siswa untuk belajar menurut cara dan keadaan masing-masing.

Perilaku 4: Bahwa guru menggunakan berbagai jenis metode mengajar serta pendekatan multimedia.

\section{Kesimpulan}

Dalam penelitian ini, penulis dapat menyimpulkan, sebagai berikut:

1. Pelaksanaan CBSA dapat meningkatkan prestasi belajar siswa, terbukti bahwa pada nilai rata-rata bidang studi $\mathrm{PKn}$, setelah menggunakan metode CBSA nilai rata-rata menjadi 7,85 (tujuh koma delapan lima).

2. Guru pada umumnya telah berperilaku sesuai dengan kaidah CBSA (indikator CBSA), terlihat bahwa:

a. Adanya usaha mendorong, membina gairah belajar dan partisipasi siswa secara aktif.

b. Bahwa peranan guru tidak mendominasi kegiatan pembelajaran saja, tetapi juga memberi kesempatan kepada siswa untuk belajar menurut cara dan keadaan masing-masing.

c. Bahwa guru menggunakan berbagai jenis metode mengajar serta pendekatan multimedia. 
3. Anak didik atau siswa selain mendapat dorongan dari pihak guru, mereka juga harus mempunyai watak atau karakter untuk belajar secara mandiri, hal ini dapat dilihat dari:

a. Keinginan, keberanian menampilkan minat, kebutuhan dan permasalahannya.

b. Keinginan dan keberanian serta kesempatan untuk berpartisipasi dalam kegiatan persiapan, proses dan kelanjutan belajar terlihat dalam penampilan berbagai usaha atau kekreatifan belajar dalam menjalani dan menyelesaikan kegiatan belajar mengajar sampai mencapai keberhasilannya dan juga ada dukungan dari kepala sekolah dan fasilitas yang ada.

c. Kebebasan dan keleluasaan melakukan hal tersebut di atas tanpa tekanan guru atau pihak lainnya (kemandirian belajar).

4. Suatu program tidak terlepas dari faktor penghambat. Penghambat dari pelaksanaan CBSA ini adalah

a. Dari pihak guru, pada umumnya kurang memperkaya dirinya dengan pengetahuan (kognitif) terhadap bahan pengajaran yang ada di lingkungan sekitarnya yang sebenarnya dapat dimanfaatkan.

b. Dari pihak anak, pada umumnya anak sejak usia Sekolah Dasar kesadaran belajarnya masih kurang.

c. Dari pihak orang tua, sebagian besar orang tua siswa kurang berkomunikasi dengan guru terhadap pembinaan moral anak.

Dari hasil analisa data sebagaimana yang tersebut pada bab IV, bahwa hasil belajar siswa Sekolah Menengah Pertama (SMP) Bhina Karya Rongkop, Gunungkidul, sebagian besar di atas standar sedang atau cukup, dengan kata lain termasuk tinggi hal ini, karena peranan guru, murid, serta orang tua.

Untuk itu penulis ingin memberikan atau mengemukakan saran sebagai berikut:

1. Walaupun basil belajar siswa tinggi namun, para siswa tetap harus berusaha meningkatkan Cara Belajar Siswa Aktif, karena dengan mempunyai kemampuan cara belajar aktif yang tinggi kelak siswa akan dapat menyelesaikan masalah-masalah pada pendidikan yang lebih tinggi atau sebagai bekal untuk menghadapi masalah-masalahnya sendiri yang kompleks. 
2. Hendaknya para guru senantiasa tetap membimbing para siswa untuk meningkatkan Cara Belajar Siswa Aktif baik secara langsung maupun secara tidak langsung agar hasil belajar yang tinggi dapat tetap dipertahankan.

3. Sekolah hendaknya berusaha untuk melengkapi fasilitas yang dapat meningkatkan Cara Belajar Siswa Aktif sehubungan dengan hasil belajar siswa dan bagi orang tua. Orang tua hendaknya selalu mendorong atau memberikan motivasi pada anaknya untuk meningkatkan Cara Belajar Siswa Aktif dan prestasi belajar siswa.

\section{Daftar Pustaka}

Conny, Semiawan, dkk. (1984), Pendekatan Keterampilan Proses, Jakarta: PT Gramedia.

Departemen Pendidikan dan Kebudayaan RI (1998), Kamus Besar Bahasa Indonesia, Jakarta: tnp.

JJ. Hasibuan dan Moedjiono (2000), Proses Belajar Mengajar, Bandung: Remaja Rasdakarya

Misbah, Partika (1989), Cara Belajar Siswa Aktif, Apa dan Bagaimana, Cianjur: PT Intan Pariwara.

MPR R1. (1993), GBHN Ketetapan RI, Yogyakarta: Pustaka Pelajar.

Muhammad, Ali (1987), Guru Dalam Proses Belajar Mengajar, Bandung: Sinar Baru.

Nana, Sudjana (1981), Cara Belajar Siswa Aktif Dalam Proses Belajar Mengajar, Bandung : Sinar Baru.

Noeng, Muhadjir, dkk. (1981), Kapita Selekta Penelitian, Jakarta: tnp.

Nursid, Sumaatmadja (1984), Perspektif Studi Sosial, Bandung: Alumni.

Oemar Hamalik (2009), Pendekatan Baru Strategi belajar Mengajar berdasarkan CBSA, Bandung: Sinar Baru Algensindo

Winanio, Surachmad (1978), Dasar Dan Teknik Research Pengantar Metodologi Ilmiah, B andung: CV Tarsito. 